\title{
Travel Characteristics and Commuting Pattern of Lagos Metropolis Residents: an Assessment
}

\author{
OSOBA, Samson Babatunde
}

Received: 2703 2015/ Accepted: 23042015 / Published online: 30062015

(c) 2015 Faculty of Geography UGM and The Indonesian Geographers Association

\begin{abstract}
Urban travel is not solely the function of travel, but also on people's participation in activities and how these were done. This study utilized 2,500 households' samples in Lagos metropolis. The questionnaire about intra-city trip patterns was administered in direct proportion to the population size of each Local Government Areas (LGAs). Systematic sampling technique was used to select every tenth building on the identified streets. It is observed that more than 95\% of residents depends on roads, while less than 5\% depends on Rail and Ferry. Work and business trips characterized the weekdays, while social, shopping and recreation trips dominate the weekends. This situation leads to too many vehicular traffic on the roads during the peak periods, leading to congestion and loss of valuable man-hours. Transportation planners in Lagos need to develop alternative intra-city transportation systems.
\end{abstract}

Keywords: Travel patterns, Intra-city trips, Residents, Policy makers, Lagos

\begin{abstract}
Abstrak Urban travel bukan hanya fungsi dari perjalanan saja, namun juga pada partisipasi masyarakat dalam aktivitas-aktivitasnya dan bagaimana aktivitas-aktivitas tersebut dilakukan. Sampel penelitian terdiri dari 2.500 rumah tangga di Kota Metropolitan Lagos. Kuesioner, yang berisi pola perjalanan dalam kota anggota rumah tangga, dibuat secara proporsional terhadap ukuran populasi masing-masing Local Government Areas (LGA). Teknik sampling sistematis digunakan untuk memilih tiap sepuluh bangunan di jalan-jalan yang diidentifikasi. Hasil penelitian menunjukkan bahwa lebih dari 95\% penduduk bergantung pada jalan raya, sementara kurang dari 5\% penduduk bergantung pada Kereta dan Ferry. Perjalanan kerja dan bisnis mencirikan hari kerja, sedangkan perjalanan sosial, belanja dan rekreasi mendominasi akhir pekan. Situasi ini membuat terlalu banyak lalu lintas kendaraan di jalan-jalan selama periode puncak, yang menyebabkan kemacetan dan hilangnya jam kerja manusia yang berharga. Para perencana transportasi di Lagos perlu mengembangkan alternatif sistem transportasi dalam kota.
\end{abstract}

Kata kunci: pola perjalanan, perjalanan dalam kota, Warga, pembuat kebijakan, Lagos

\section{Introduction}

Spatial interaction in urban setting could be of at least two types namely; those that involve physical contacts like day-to-day movements of people and those that do not require such contact like telephoning. Particularly important movements in urban analysis are the day-to-day movements of people. This is because they represent both a function and a process [Ayeni, 1979; Axhausen and Gariling, 1992]. They represent functions as long as they perform the duty of maintaining the status quo in the spatial relation of different parts of the city, while they represent processes when changes in their volume, intensity and direction come to determine the pattern of growth and organization of the spatial structure of the city.

Human movements made possible by transport, provide vital clues to the understanding of human

OSOBA, Samson Babatunde

School of Management Sciences, National Open University of Nigeria.

Email: monitunde@yahoo.com spatial behavior in all cities especially in developing countries where measures of telecommunication are not likely to prove of much value, given the low level of technology and the generally poor economic conditions. Transportation is a very vital component to urban life because it is an absolutely necessary means to an end. It allows people to carry out the diverse range of activities that made up daily life [Filani, and Osayinmese, 1979; Filani, 1991; Filani, 1993]. The fact that cities consist of spatially separated and highly specialized land uses such as, food stores, hardware stores, banks, drug stores, hospitals, libraries, schools, post offices and so on, people must travel if they want to obtain necessary goods and services.

Worldwide, urban travel takes place when inhabitants of urban center carry out their different activities in different places whether by necessity or by choice. Studies [Ayeni, 1974; Adeniji, 1981] have shown that in general, people tend to travel in order to obtain access to a variety of other individuals, services and facilities that are not available at the origins of their 
journeys. To what extent, how far and by what means they travel is a result of a complex interaction of socioeconomic, political and physical factors [Adeniji, 1991]. The nature and degree of influence of these factors however, vary from city to city and even within a given urban centre [Hausa and Schwab, 1987; Gordon et al., 1988; Rimmer, 1986; White 1990; Garling et.al., 1994, Bhat and Koppelman, 1999].

Owen [1987] noted that "mobility has become an integral part of education, access to sports, and the amount of international trade, travel and investment". Movement patterns within the cities can be categorized as being of either short-term or long-term duration. Short-term or daily movement consists of trips involving some activities such as work, shopping and recreation, whereas long-term or more permanent movement involves changing residence.

Urbanization is the very embodiment of communication. By concentrating a wide variety of creative specialists in a region of limited extent and of high connectivity, cities minimize the need for costly movement of goods and people. This is most evident in the central business areas oflarge cities such as the Lagos metropolis where the chief executives of major firms and public agencies have the opportunities to face-to-face exchanges. These urbanization benefits are achieved, however, at the price of overcrowding, congestion, excess demands on the natural environment, and people to outlying areas. The root of this dilemma (the need for specialized interaction, information, the desire for "elbow now" and amenity) is partly the product of temporal and spatial constraints on human behavior.

In urban transportation, the movements of people as they go about their daily activities are of great concern [Giuliano, 1998]. Thus, urban transport studies are concerned with what people do, as well as where, how and when they do it and also what choices and constraints lie behind the "what", "where", "how" and "when" patterns of behavior [Hanson, 1995]. In other words, urban travel is not solely on travels alone, but on people's participation in activities and how this is done.

Lagos metropolis was selected as the study area because it has an increasing demand on the information of intra-city travel pattern. .This study assess travel characteristics and commuting pattern among the urban residents in the Lagos metropolis and also assist the urban transport policy makers to understand the trip pattern characteristics of urban residents in the Lagos Metropolis.

\section{The Methods}

Both primary and secondary data were used for this research work. The first data set, which is the primary data was collected through the use of structured questionnaires administered on the urban metropolitan residents in order to determine their socio economic characteristics, such as income, occupational status, age, marital status, household size, travel pattern. The second data set, the secondary data, was gathered from journal articles. Since there was no fast and hard rule guiding the choice of sample size, in order to determine the sample size, the estimated number of households which was 3,232,084, was taken from the population size. ,. Bruton [1975] and Neuman [1994] recommended sample size between $10 \%$ and $1 \%$ for population areas of under 50,000 and 1 million respectively. However, Olokesusi [1994], Solanke [2004] and Havlicek [1985] utilized a sample size of less than $1 \%$ in their studies. In light of these, a sample size of $0.08 \%$ of questionnaires was administered while 2,500 questionnaires were returned. In order to determine the number of households to be sampled in each of the Local Government Areas (LGAs) that constituted Lagos Metropolis, the calculated percentage $(0.08 \%)$ was multiplied with the estimated number of households in each Local Government Area (LGAs)

One type of sampling methods was considered appropriate in this study. This is the Simple Random method. In each of the neighborhoods surveyed, random sampling was used to select the number of identified streets and it was also used to distribute the questionnaire among the households in each of the neighborhoods surveyed. In case of multi-family unit, one household was interviewed while random sampling was used to select samples of number of household buildings in which target respondents reside.

The questionnaire was structured into two parts, sections $\mathrm{A}$ and $\mathrm{B}$. The first part considered the socioeconomic characteristics of the respondents. The second part of the questionnaire dealt with the travel and activity pattern of urban residents. The information requested covered the details characteristics of the household trips for different purposes and for different days of the week. The basic question here included the mode-choice, purpose of trip, time spent on the journey and trip length. All the possible trips were divided into five purposes namely, work, shopping, recreation, social, and business trips. During the collection of this information on travel activities, the questionnaire was given to urban residents for a week (Monday - Sunday). Thus, the questionnaire served as a self-administered travel diary and it was later collected after the seven days of a week.

Urban residents were requested to construct their urban trips within one week. The selection of a full week travel was to be able to cover the totality of trips made by people both on weekdays and weekends. The reason for giving them the questionnaire to fill and record their trips activities for a week was to collect information from people while it was still fresh in their memory, thus enhancing the accuracy of the information. The questionnaire survey covers urban residents on household basis. A household is defined as persons living under the same roof and eating from the same pot. Following the works of Oyesiku [1990] and Dimitriou 
[1995], household is a well-known key decisionmaking unit for the general description of residents' daily travel characteristics. It provides considerable insight into the quality of life experienced and the extent of similarities and variations in their commuting patterns among different areas within the Lagos metropolis. Following the works of Olayemi [1977], Hanson [1995] and Solanke [2004], the four measures of trips characteristics chosen are namely, departure time, arrival time, mode of transport and trip length for each intra-city journey purposes. Trip purpose analysis is necessary for an in-depth knowledge of the aggregate patterns of intra-city travel. Such analysis revealed the structure of the movement by households and the different land uses to which certain proportion of the aggregate journeys are directed. The total numbers of trips made in the entire Lagos metropolis during the survey period was 24,388 . With these, trips to work accounted for $44.3 \%$ while those to business activities constituted $33.4 \%$. Thus, journeys to work places and business activities in the area accounts for more than two thirds of all trips. These two were followed by social activities (9.6\%), shopping activities(7.9\%) and recreation activities which accounted for about $(4,9 \%)$. Simple frequency calculation was used to analyzed the collected data.

In spatial interaction studies, the ideas of specific geographic complementarities and the friction of distance are brought together in the gravity model. The gravity model has captured a great deal of attention because of its pervasive simplicity. In the social sciences, the gravity model has been used to explain such of the variation in data describing movement of people, good and ideas, and insights about geographic structures formerly hidden. The gravity model is thus a valid representation of facts about spatial interactions. The model has been used in the works of Filani (1972), Okafor [1976], Oyesiku [1990], Solanke [2004]. The simple gravity model assumes that the interaction between two towns is the product of their masses (population, employment, income) and inversely proportional to the distance separating them.

Spatial interaction system is influenced by three factors, complementarity, depending on a real differentiation, which results in a supply at one place meeting a specific demand at another place,the intervening opportunities between and transferability.

Complementarity refers to the presence of a demand or deficit at one location and a supply or surplus at another without which there is no economic rationale for any movement. A work place such as factory or office tower is an example of a place with a demand for labor while a residential neighborhood provides a source of workers. A sawmill requires logs while a forest provides them. To adopt a metaphor from physics, complementarity is like a potential gradient with goods and people flowing from a higher energy state where they are in surplus to a lower energy state, where they are in deficit. From the realm of physical geography, wind is the flow of air between complementarity atmospheric zones from a high pressure cell to a low pressure cell.

Transferability refers to the cost of overcoming distance measured in real economic forms of either time or travel cost. The cost of overcoming distance is known as the "friction of distance". If the friction of distance is too great, interaction will not occur in spite of a complementary supply demand relationship. Friction of distance depends on prevailing transportation technology and the price of energy. In globalization and the emergence of megacities, daily commuter flows, for example, are always subject to a travel time constraint with two hours being a typical maximum for the oneway daily journey to work. /High-value, low-weight goods such as jewelry are imminently transferable and exported on a global scale while heavy, low-value goods such as concrete blocks are usually used very close to where they are produced.

Intervening opportunity is the third basis for interaction, although it is typically considered as the reason of interaction between two complementary locations. Complementarity will only generate a flow if there is no intervening or closer location. The flow of goods that would otherwise occur between two complementary, locations may be diverted to a third location if it represents a better intervening opportunity with a cheaper overall cost of transportation. However, Ullman (XXX) noted that the trade diverting effect of an intervening opportunity could eventually facilitate interaction between more distant complementary locations. In his example, the nearest (intervening) source of logs would justify the construction of a short logging railway from the will to the forest resource, and when it was harvested, the railway would be extended to the next intervening opportunity and so on until it ultimately reached a more distant complementary location. Flows to the more distant complementary locations might never have been established had the transportation infrastructure not been constructed in a series of intervening opportunities.

Because of its simplicity, the spatial interaction model and the gravity model have been widely used, and since the work will determine the nature of human flow from one zone to another zone, the model was employed.

\section{Result and Discussion}

Table 1. shows the characteristics of intra-city work trips in Lagos metropolis. This table emphasizing the similarities and variations in departure and arrival time, modal split and length of trips of workers in all the fifteen Local Government Areas that constitute Lagos metropolis. From table 1, the residents who are workers in all the fifteen Local Government Areas that constitute Lagos metropolis have substantial proportions of work trips peak between 6.01 and $6.30 \mathrm{am}$. High proportion 
of work trips peak period are made in Somolu (74\%) followed by Kosofe (73\%), Oshodi-Isolo (72\%), EtiOsa (72\%), Alimosho (71\%), Mushin (70\%), Agege (70\%), Surulere (69\%), Ifako-Ijaye (69\%), Apapa (69\%), Amuwo-Odofin (66\%), Ojo (63\%), Ikeja (62\%), LagosIsland (61\%) and Lagos-Mainland (60\%).

This may =because the earlier take-off of workers in all the fifteen Local Government areas might be connected with the chaotic traffic situation in Lagos metropolis and their need to get to work on time. Similarly, where there was low proportion of workers set-out between 6.01 and 9 am or beyond, we have workers who are made up of traders and other workers in the informal sector with no definite time for commencing their daily activities.

For the after-work journey, Table 1 shows that residents who are workers in all the fifteen Local Government Areas that constitute Lagos metropolis account for $80 \%$ of workers who return home late between 6.31 and 9.30 pm every working day while the remaining $20 \%$ account for workers who return home early between $3.30 \mathrm{pm}$ and $6.30 \mathrm{pm}$ every working day.

From the aforementioned explanation, it is very clear that the variation in the nature of residents' job, especially with those who work in the private sector makes it imperative for them to arrive home late while those who work in the public sector (especially civil servants) return home earlier.

From the table, it is generally observed that the reason for returning home late by the residents may be as a result of the delay necessitated by the chaotic traffic situation in Lagos metropolis.

The modal split for work trips, in order of importance across the Lagos metropolis are: commercial vehicles, private vehicles, official vehicles, motorcycles, Rail and Ferry. Table 1 above shows that the highest proportion (between $32 \%$ and $61 \%$ ) of workers in all fifteen Local Government Areas that constitute Lagos metropolis made use of commercial vehicles, followed by private vehicles (between $17 \%$ and $36 \%$ ); official vehicles (between $13 \%$ and $26 \%$ ); motorcycles (between 1\% and 19\%), while the Rail and Ferry have the lowest proportion of all, which is between $1 \%$ and $3 \%$ of workers and between 0 and $2 \%$ of workers for Rail and Ferry respectively.

The distance in kilometer from the table above shows that there was variation in the distance workers had to travel before getting to their various places of work in all the fifteen Local Government Areas that constitute Lagos metropolis. Over $60 \%$ of workers who travel over a distance of between 15.1 and 30 $\mathrm{km}$ to work are in the Local Government Areas such as Agege, Ojo, Amuwo-Odofin, Alimosho, Kosofe, Ifako-Ijaye, Oshodi-Isolo, Somolu, Mushin, Surulere, while the remaining proportion declines gradually with decreasing distance (between 5 and $15 \mathrm{~km}$ ) from home. The workers in these categories were those in the local government areas such as Apapa, Eti-Osa, Ikeja, Lagos-

\section{Island, and Lagos Mainland.}

The above can be explained by the proximity of the commercial centers and industries to the workers home in the Lagos metropolis.

Table 2 shows the characteristics of intra-city business trips in Lagos metropolis. Table 2 emphasizes the similarities and variations in departure and arrival time, modal split and length of trips of workers in different urban centres of Lagos metropolis. From the table 2 , in the same manner, the highest proportion of workers in all the fifteen Local Government Areas of Lagos metropolis make their trips in the peak period between 6.01am and 6.30am of every working day and such workers are in the Local Government Area such as Somolu with the highest proportion (78\%), followed by Oshodi-Isolo (75\%), Mushin (73\%), Ifako-Ijaye (73\%), Surulere (71\%) Alimosho (71\%) Kosofe (71\%) LagosIsland (70\%), Eti-Osa (70\%), Lagos Main Land (69\%), Amuwo-Odofin (69\%), Agege (69\%), Apapa (69\%), Ojo (65\%) and Ikeja (64\%).

This could be attributed to the fact that residents in the business category in Lagos metropolis leave home early as a result of the delays usually encountered on their way home due to traffic congestion. The relative proportion of residents within the business category that set-out between 7.01 and 9 am or later could be explained by the proximity of their business activities to their homes.

In the same manner, like work trips, business trips show that $80 \%$ of residents who engage in business activities arrive home late between $6.31 \mathrm{pm}$ and $9.30 \mathrm{pm}$ or thereafter on every business day while the remaining $20 \%$ belongs to those who return home earlier between $4.31 \mathrm{pm}$ and $6.30 \mathrm{pm}$ on every business day.

The above explanation could be attributed to the type of business activities being engaged in by the residents. This study further shows that those who arrive home late must have done so as a result of traffic hold up, which occur on daily basis in every part of Lagos metropolis.

The modal split for business activities in the Lagos metropolis reveals the use of Commercial vehicles, private vehicles, motorcycles, rail and ferry in the order of importance in the various urban centers. This study further shows that commercial vehicles and private vehicles carry substantial proportion of over $80 \%$ of residents who engage in business activities in each of the fifteen Local Government areas that constitute the Lagos metropolis.

The distance in Kilometer for business trips reveals that $70 \%$ of residents who engage in business activities in each of the fifteen Local Government Areas that constitute Lagos metropolis do not travel over a long distance, like the case of work trips, whose travel distance is between 5 and $20 \mathrm{~km}$. The remaining $30 \%$ of residents who engage in business activities do travel a long distance, between 20.1 to $30 \mathrm{~km}$ or beyond.

As observed in Table 1 and 2, work and business 


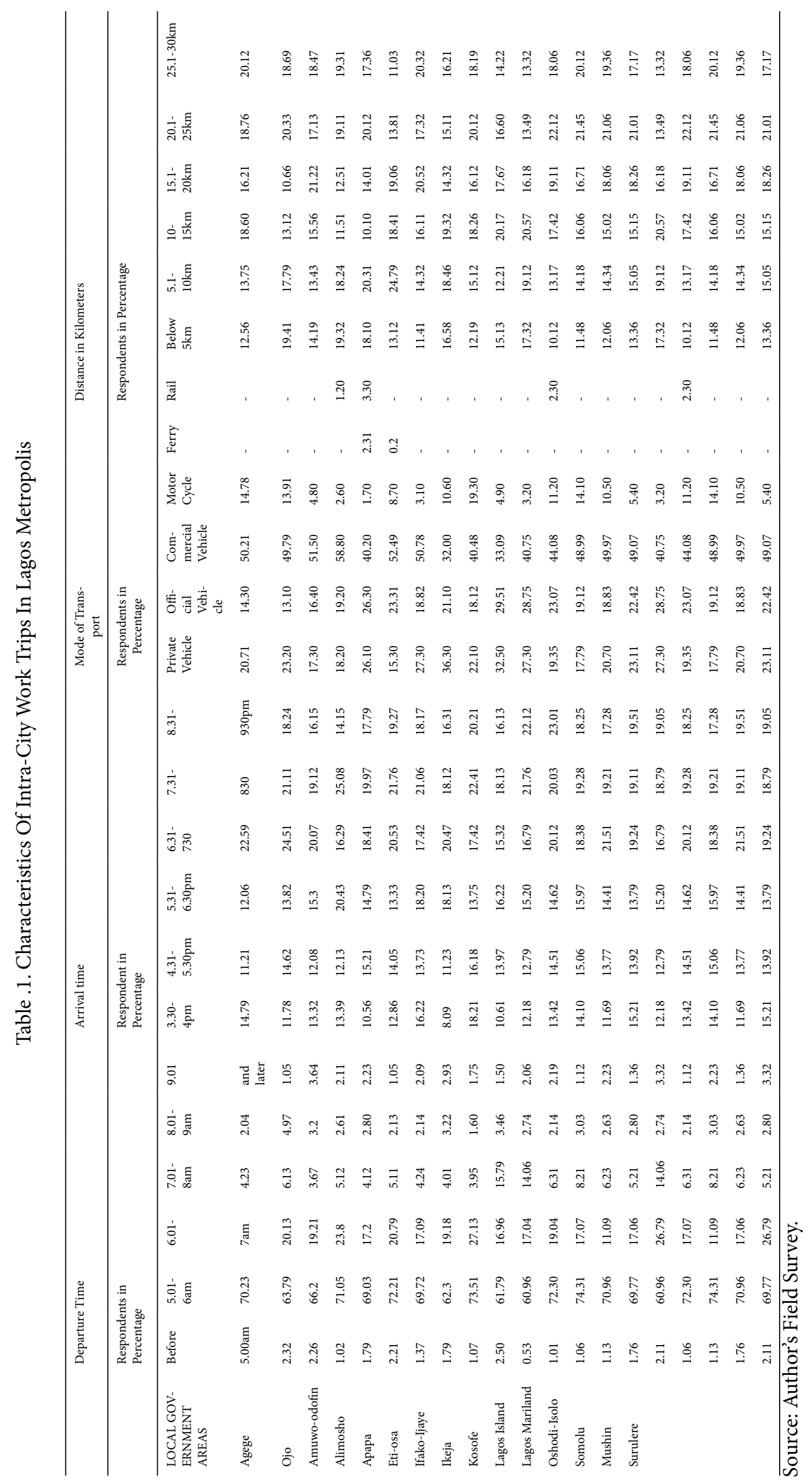




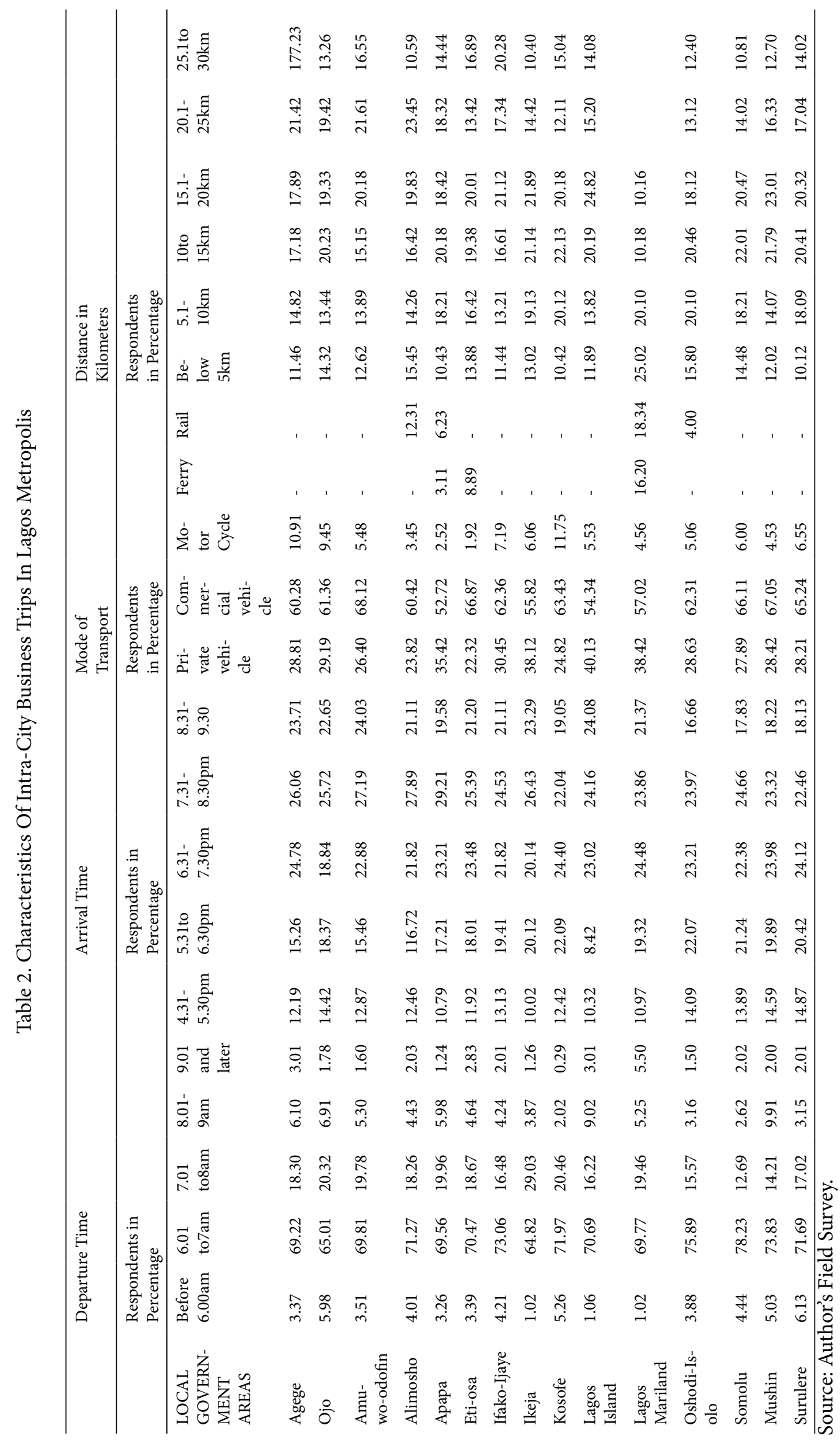


trips dominate weekday travels. However, unlike other trips, their characteristics show that work and business trips have their peak periods between 6.01 and $6.30 \mathrm{am}$. . These findings confirm the remarks made by Olayemi [1977] and Bawa-Allah [2006] that Lagos metropolis is where both work and business journeys have their peak between 6.01 and $6.30 \mathrm{am}$.

On the other hand, in comparison with other trips earlier discussed, (the work and business trips), Table 3 shows that the residents in each of the fifteen Local Government Areas that constitute the Lagos metropolis engage in social travels at different times of the day. However, the table reveals that $80 \%$ of the residents in each of the Local Government Areas engage in social trips between $8 \mathrm{am}$ and 12 noon and 12.01 to $5 \mathrm{pm}$, while the remaining $20 \%$ of residents made their social trips between $5 \mathrm{pm}$ and later in the day.

The after-social trip journey shows that low proportion (less than 25\%) returns home earlier than $5.01 \mathrm{pm}$ every day in each of the fifteen local Government areas, while the largest proportion (over $70 \%)$ returns home later between $5.01 \mathrm{pm}$ and later in the night from their social trips.

The modal split for social travel is similar to other journey purposes, with the use of commercial vehicles, private vehicles, motorcycles, Rail and Ferry in order of importance in the various urban centers of Lagos metropolis. In the same manner, this study reveals that commercial and private vehicles carry substantial proportion (over $80 \%$ ) of residents who engage in social trips while the remaining low proportion (20\%) make use of other modes (motorcycle, Rail, and Ferry)

The distance in kilometers of social trips reveals that residents in each of the fifteen Local Government Areas engage in social travels at different distances each day. However, as shown in Table 3, high proportion (over $75 \%$ ) of residents travels between 5 and $20 \mathrm{~km}$ each day while the remaining proportion (less than 25\%) of residents travels between 20.1 and $30 \mathrm{~km}$ everyday in each of the fifteen Local Government Areas of Lagos metropolis.

Table 4 reveals that shopping activities occur throughout the day in all urban centres while the residents engage in this trip at earlier period of the day. However, the study shows that over $80 \%$ of residents engage in shopping trips between 12 noon and $4 \mathrm{pm}$ in each of the fifteen local Government areas while the remaining $20 \%$ engage in shopping travels between $4.01 \mathrm{pm}$ and beyond.. Conversely, the residents' return journey from shopping is at a later time in the day and this has high proportion (over 60\%), while the remaining (less than 20\%) of residents that engage in shopping activities return home earlier.

In the same manner, Table 4 reveals that the modal split for shopping journeys is not different from other journey purposes with the use of commercial vehicles, private vehicles, official vehicles, motorcycles, Rail and Ferry in order of importance in each of the fifteen local
Government areas. This study reveals that commercial and private vehicles carry substantial proportion (over 70\%) of residents who engage in shopping trips, while the remaining low proportion (less than 30\%) of residents who engage in shopping travels in each of the fifteen Local Government Areas is carried by rail and ferry.

The distance in kilometers of shopping travels in each of the fifteen local Government areas shows the desire of the substantial proportion (over 70\%) of residents to do shopping activities within $15 \mathrm{~km}$ radius of their residences, while the remaining $30 \%$ of residents desire to do shopping activities beyond the 20 $\mathrm{km}$ radius.

The analysis of recreation trips characteristics reveals that like shopping trips, there is a level of uniformity in the departure time for this journey purpose in each of the fifteen local Government areas. However, this study shows that higher proportion (over $60 \%$ ) of residents engage early in recreational trips between $11 \mathrm{am}$ and $4 \mathrm{pm}$ each day while the relative proportion (less than 30\%) of residents engage in recreational trips late between $4.01 \mathrm{pm}$ and later in the day. The return journey of recreational trips shows that $80 \%$ of residents who engage in recreation activities travels home late between 4.01 and late in the day while the relative proportion of $20 \%$ of residents who engage in recreation trips returns home early in the day in each of the fifteen Local Government Areas.

The study reveals that the modal split for recreational trips is not different from other journey purposes with the use of commercial vehicles, private vehicles, official vehicles, motorcycles, Rail and Ferry. The Table 5 shows that higher proportion (over 75\%) of residents make use of commercial and private vehicles for recreational trips while relatively proportion (less than 25\%) of residents make use of official vehicles, motorcycles, Rail and Ferry.

Table 5 shows that recreation trips take place at varying distances from homes in each of the local Government areas. However, this study reveals that substantial proportion (over 70\%) of residents travel a distance of less than $15 \mathrm{~km}$ radius of their residences, while relatively proportion (less than $30 \%$ ) of residents engage in recreational trips of distances of over $20 \mathrm{~km}$ radius of their residences,

\section{Conclusion}

Generally, this study reveals detailed characteristics of each of the trip types on the basis of four features, namely: departure time, arrival time, model of travel and distance in kilometers. The regular pattern of journeys for work and business activities have similar opening and closing hours. This study shows that 6.01 -6.30 am and $6.31-8.30 \mathrm{pm}$ constitute the morning and afternoon peak periods respectively for the work and business trips in each of the fifteen Local Government areas that constitute the Lagos metropolis. 


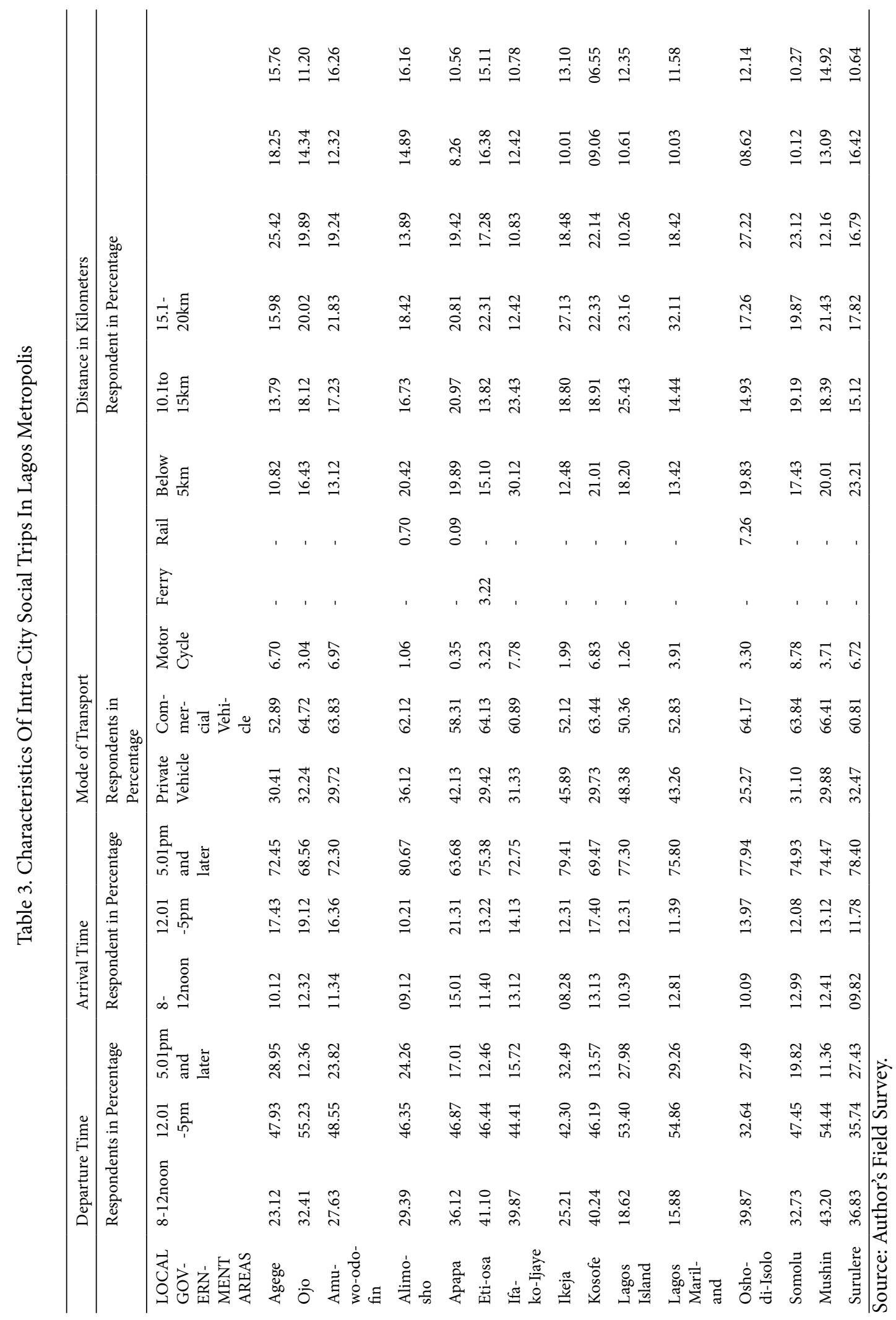




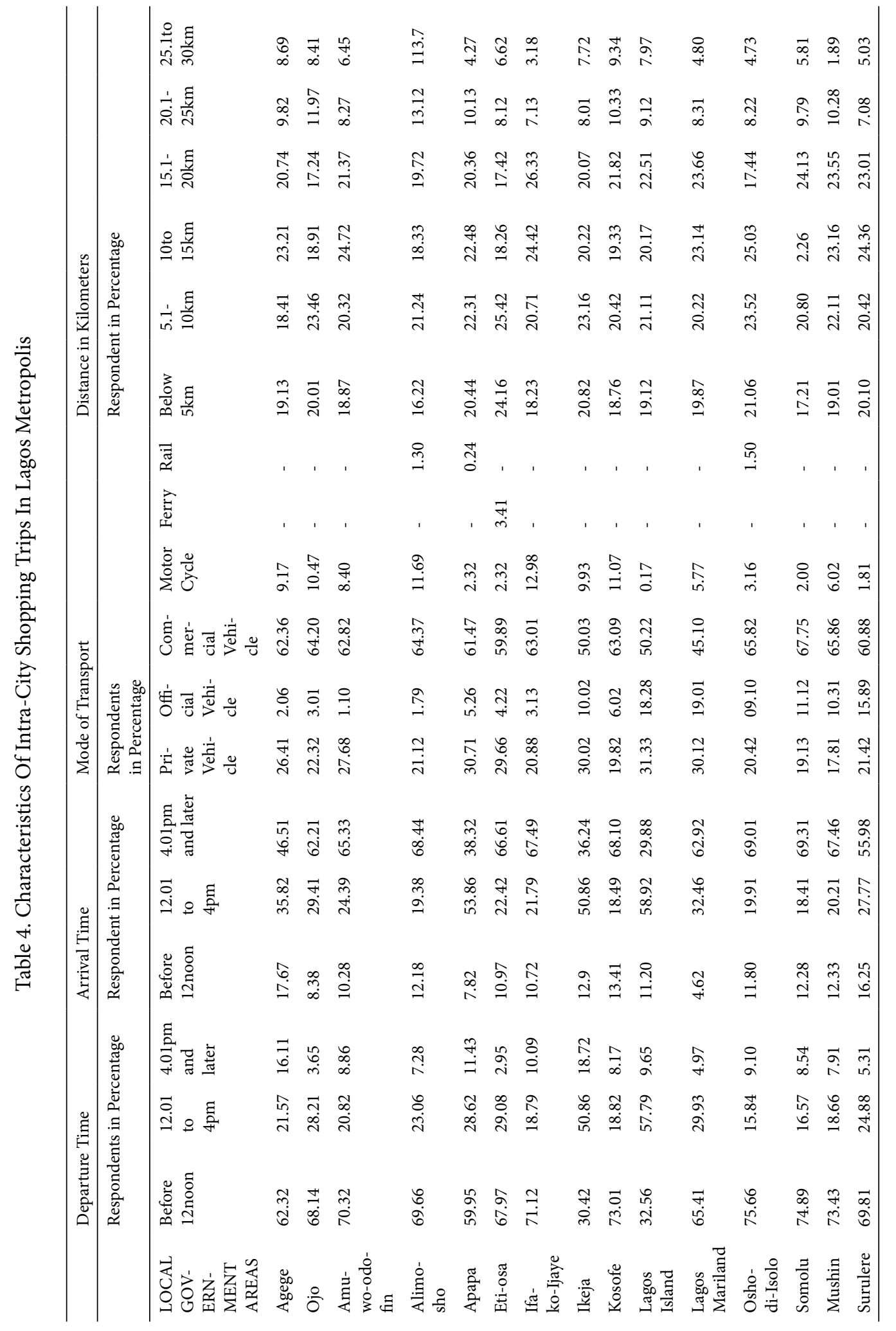




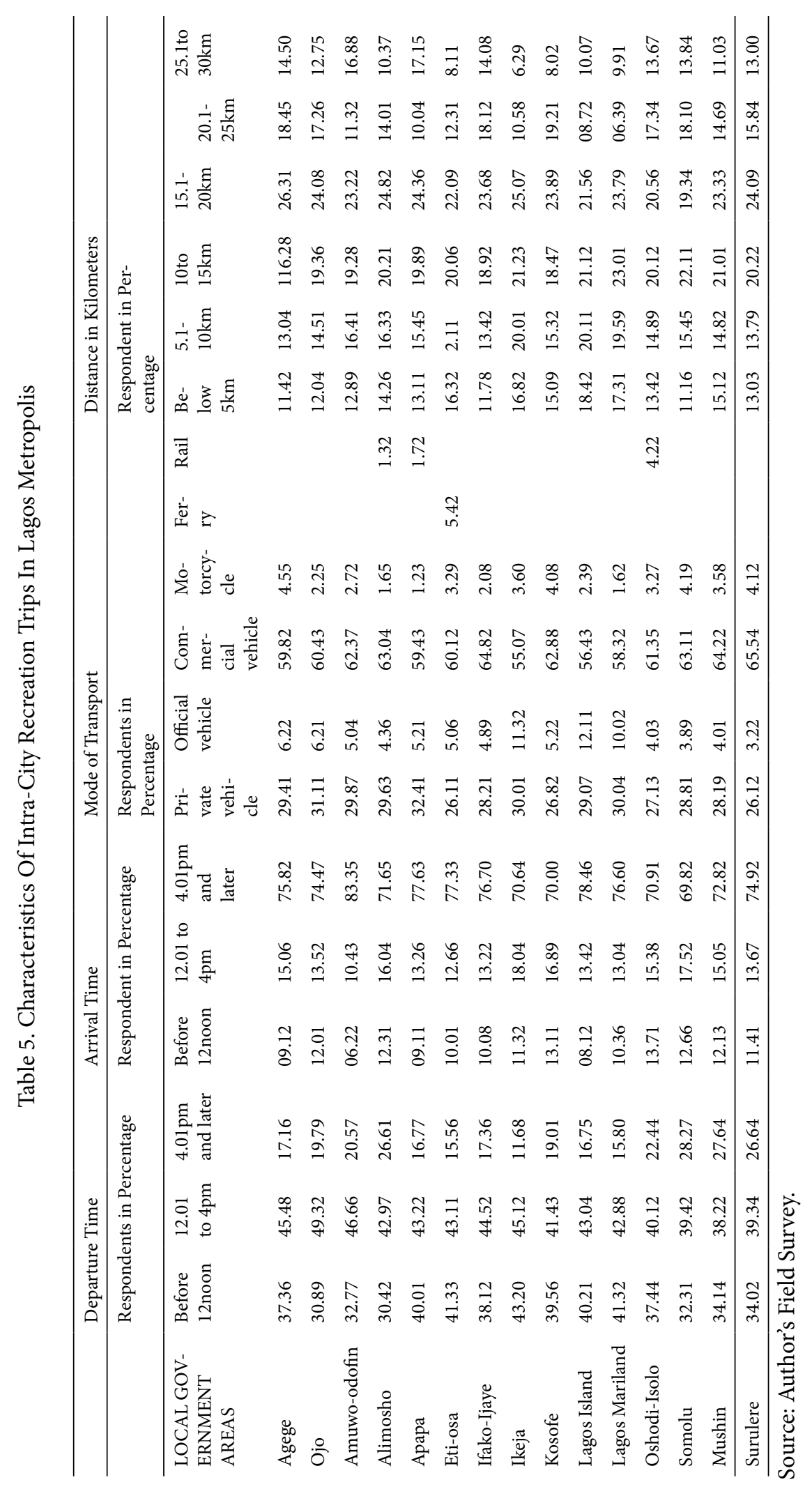


However, the regular pattern of journeys for shopping, and recreational trips reveals a different pattern of trips. This study shows that the residents travel for shopping and recreational activities before 12 noon and return after $5 \mathrm{pm}$ every day, while the residents depart for social activities at 8 am and return home later after 5 pm every day.

In the area of the modal split, the study reveals that the majority of residents in each of the fifteen local Government areas make use of similar modes of transport which are commercial vehicles, private vehicles, official vehicles, motorcycles, rail and ferry to their various trip purposes. However, it is observed that more than $95 \%$ of residents depend on the road while small proportion (less than 5\%) of residents depends on other modes (i.e. Rail and Ferry) of transport.

\section{References}

Adeniji, S.A. (1981),Public Transportation and Urban Development strategy in Nigeria,Unpublished Ph.D Thesis University of Wales, Pontain.

Adeniyi, K. (1985),Urban Transportation System in Nigeria" ODU:A Journal of West African Studies, 28,81-97.

Adeniji, K. (1991),Urban Mobility Crisis, where do we go from here?, Paper delivered at Ogun State Public Service Forum Gateway Hotel, Abeokuta.

Adeniji-Soji, J.O. (1996), Patterns of Telecommuting and Intra-city travel: A case study of Ibadan metropolis, Nigeria, Unpublished Ph.D Thesis, Department of Geography, University of Ibadan, Ibadan.

Adeniji 'Kunle (2000), Transport challenges in Nigeria in the next to a declares" Transport studies Unit NISER Ibadan.

Axhausen, K.W. and Garling T. (1992), Activity Based Approach to Travel Analysis, Conceptual Framework, Models and Research Problem Transport Reviews 12 (4) pp. 323-341.

Ayeni, B (1979), Concepts and Techniques in Urban Analysis. Croom Helm Ltd, London.

Ayeni, M.A.O. (1974), Predictive Modelling of Urban Spatial Structure: the example of Jos, BenuePlateau State, Nigeria. Unpublished Ph.D. Thesis, University of Ibadan. Balinger, Cambridge, Massachutts.

Bawa-Allah, T.O. (2006), Integration of Urban Public Transport System in Lagos Metropolis. Unpublished PhD Thesis, Centre for Transport Studies, Olabisi Onabanjo University, Ago-Iwoye.

Bhat C.B. and Koppelman, F.S. (1999), A retrospective and prospective surveyprospective survey of time use research, Transportation" Transportation 26, 119-139.

Bruton, M.J. (1975), Introduction to Transport Planning. Hutchinson, London.

Dimitriou, H.T. (1995), A Development Approach to Urban Transport Planning: An Indominian Illustration, Avebury, Ashgate Publishing Limited.
The study reveals that there is variation in distance in kilometers travelled by residents to the various journeys of purpose in each of the fifteen Local Government Areas in Lagos metropolis. The distance in kilometers travelled by residents depends on the proximity of the area to their various journeys purpose within the Lagos metropolis. The implication of this situation is the presence of too many vehicular traffic on the roads during the peak periods leading to congestion and loss of valuable man-hours in the Lagos metropolis. It is therefore recommended that transportation planners in Lagos need to develop alternative intra-city transportation systems. This can be achieved through the development of other new land transportation systems by policy makers.

Filani, M.O. (1991), Mobility Crisis in Nigeria Federal Government's Mass Transit Programme" Annals of the Social Science Council of Nigeria No3, pp.1330.

Filani, M.O. (1993), Transport and Rural Development in Nigeria,Journal of Transport Geography vol. 1, No.4, pp. 248-254.

Filani, M.O. and Osayinmese, I.Z., (1979), Intra-city Traffic Flow Problems in Nigeria, The Nigerian Geographical Journal, vol.22, No.1, pp.17-31.

Garling T. Kwan and Golledge R.G. (1994), Computational Process Modelling of household activity scheduling, Transportation Research 28B (5) pp. 355-364.

Giuliano, G., (1998), Information technology, work patterns and intrametropolitan location: A case study; Urban Studies, 35(7),1077-1095;.

Gordon P., Kumaar, A and Ricahrdson, H.W. (1988), Beyond The Journey to work, Transportation Research A 22 419-426.

Gasper, J and Glaeser, E.L. (1998), Information Technology and the future of cities. Journal of urban economics. Vol. 43; 136-156. www.ideas. repec.org/pnbr/nberwol/

Giuliano, G. (2001),Urban Design, Telecommunication and Travel Forecasting. Keynote address. Texas Transportation Institute.

Guillan, R and Huriot, J.M. (1998), Informational Interactions and the future of cities, LATEC Discussion paper 98 - 101. Universities de Bourgogne, Dijon.

Guillan, R and Huriot, J.M. (1999), How information shapes cities: theory and facts, LATEC Discussion paper 99-105. Universities de Bourgogne, Dijon.

Graham, S and Maravin, S. (1996), Telecommunication and The City: Electronic Spaces, Urban Places. Rout ledge. New York.

Goddardd, J.B. (1970), Functional Regions within the City Centre: A study of factor analysis of Taxi flows in Central London". Institute of British 
Geographers Transaction. No. 49, pp. 161-182.

Goddardd, J.B. (1985), Office Communication and Office Location" Regional Studies Vol. 1.

Gordon, Peter and Richardson, Harry W. (1997), Are Compact Cities a Desirable Panning Goal? Journal of the American Planning Association (Winter) Vol. 63, No. 1.

Gottman, Jean (1983), Urban Settlements and Telecommunications, Ekistics.

Hoyle, B.S. and Knowles R.D. (1998), Transport Geography an Introduction, in Hoyles, B.S. and Knowles, R.D (eds) Modern Transport Geography: John Wiley and Sons pp. 1-12.

Harvey, Andrew S. and Paul A. Macnab (1998), Who's up? Global Interpersonal Temporal Access, Paper Presented at the NCGIA Specialist Meeting: Measuring and Representing accessibility in the Information Age, November 19-22, Monetary, California. Time Use Research Program, Department of Economics, Department of Geography, Saint Mary's University, Halifax, Nova Scotia, Canada.

Hausa, S. and Schwab M (1987), Accessibility and Intra urban travel, Environment and Planning pp. 735748.

Havlicek, J.J. (1985), Impart of Solid waste disposal site on Property values, in Tolley, G.S. and Havlicek, J (eds) Environmental Policy Solid waste.

Lagos State Government (2003), Lagos State 2003, Digest, Ikeja, Ministry of Economic Planning and Budget, central Office of Sttistics.

Ling, R and Yrrti, B. (1999), Nobody Sits at home and waits for the telephone to ring: Micro and hyper-coordination through the use of mobile telephone. Telenor Corporation Research Report. http://www.telenor.no/fou/prosjekter/fremt-idensBrukere/Seminarer/ mobilepresentasjoner.

Mabogunje A.L. (1968), Urbanization in Nigeria New York: African Publishing Corp.
Newman, W. L. (1994), Social research methods. Boston Allyn and Bacon.

Osoba, S. B. (2010), Influence of Global System for Mobile Communication on Intra-City Travel in Lagos, Nigeria. Unpublished Ph.D Thesis, University of Ibadan.

Olayemi, D.A. (1977), Intra-City Person Travel in Metropolitan Lagos: Study of Commuting in a fast growing capital of a developing country, Geoforum, 8, 19-27.

Olokesusi, F. (1994), Impact of Ring road solid waste disposal facility in Ibadan Nigeria, NISER Monography Series No.3.

Oyesiku, O.O. (1990), Inter-Urban travels pattern in Nigeria. A Case Study of Ogun State, (Unpublished Ph.D Thesis University of Benin City, Nigeria).

Policy News Magazine (2001), Vol.6, No. 16, April 16$22,2001$.

Turton B. (1992), Urban Transport Patterns in Hoyle B.S and Knowles R.O. (eds) Modern Transport Geography Belhaven press 67-80.

Rimmer, P. J. (1986), Rikisha to Rapid Transit: Urban Public Transport Systems and Policy in Southeast Asia, Pergamon Press, Oxford.

Solanke, M.O. (2004), Analysis of Intra-urban travel Pattern in Ogun State, Nigeria, Unpublished Ph.D Thesis, Department of Geography, University of Ibadan, Ibadan.

Susan Hanson (ed.) (1995), The Geography of Urban Transportation, Second Edition. New York: Guilford Press.

W. Owen, (1987), Transportution and World Development, Johns Hopkins University Press, Baltimore, Md, USA.

White P.R. (1990), Inadequacies of Urban public transport systems in Dimitriou H.T. (ed), Transport Planning for Third World Cities London Routledge pp. 85-116. 